Chanyalew Enyew ${ }^{1}, \mathrm{PhD}$

Department of Teacher Education and Curriculum Studies

Bahir Dar University

Solomon Melesse ${ }^{2}$, PhD

Head of Department of Teacher Education and Curriculum Studies

Bahir Dar University

Ethiopia
Original scientific paper

UDC: 37.018 .7

DOI: $10.17810 / 2015.78$

\title{
NEXUS BETWEEN BELIEFS COLLEGE ENGLISH INSTRUCTORS' HELD ABOUT TEACHING READING STRATEGIES AND THEIR CLASSROOM PRACTICE
}

\begin{abstract}
This study examined connections between beliefs college English language instructors' held about reading strategies and how they implemented them in teaching reading. The sites of the target population for this study were the Colleges of Teacher Education students in Amhara National Regional State Council, Ethiopia. In this region, there are 10 Administrative Zones. In the zones, there are 10 colleges. Among these, 4 colleges were selected by simple random sampling technique. From the 4 selected colleges, 26 instructors were selected by simple random sampling technique. Data were collected through close-ended questionnaire items and observation checklist. Data obtained from questionnaire were analyzed using percentage where the observation data were applied one sample t-test. The findings indicate that college instructors held strong beliefs about English language strategies. In spite of their strong belief, however, the research confirmed that instructors do not actually apply the strategies in their reading classes. From the findings, it could be inferred that it would be useful if instructors adjust their beliefs to practices. To help instructors connect their beliefs to their practice, there seems a need to train them on reading strategies.
\end{abstract}

Keywords: English language instructors, College, Beliefs, Teaching reading strategies, Classroom practices, Teacher education.

\section{INTRODUCTION}

\section{Background of the Study}

One of the most significant purposes of instructors in teaching English as a Foreign Language (hereafter EFL) is to assist college students acquire better reading skills and strategies. Researchers (e.g., Abebe, 2012; Abiy, 2011; Donaldson, 2011) argued that teaching students' reading skills and strategies in English language at teacher education colleges is the key for not only for teaching reading skill but also for the other language skills since foreign language context demands both teachers and students to use reading outside of class. College students' success in teaching reading in English language and other subjects in large part

\footnotetext{
${ }^{1}$ chanyalewenyew@gmail.com

2 btlhmslmn1997@gmail.com
} 
depends on the ability to read or success in reading at college level since it is a means to acquire knowledge and skill in other subjects as well (MoE, 2008). Thus, the various importance of EFL has made reading an essential skill to master by students. With strengthened reading skills, EFL readers will make greater progress and attain greater development in their present and future professional careers (Snow, 2002). According to Carrell (1988, p.1), "for many students, reading is by far the most important of the four macro skills, particularly in English as a second or a foreign language". This is also true in the case of Ethiopian teacher education colleges since the reading skill offers the students a wide range of interesting information as well as a variety of language expressions and structures which are of great use for developing other language skills and learn other subjects using English language as medium of instruction (AIR, 2012; Amlaku, 2010).

In learning reading in EFL context, however, students often experience the lack of reading skills which are essential for them to overcome the challenges in the classroom. Research into reading has found that effective readers are aware of the strategies they use and that they use strategies flexibly and efficiently. It was found that reading strategies could be taught to language learners by their teachers so that learners can become more successful in language learning. Oxford (1990) states that language learning strategies "... are especially important for language learning because they are tools for active, self-directed movement, which is essential for developing communicative competence" (p.1).Hence, teachers should consider and show their students how to use effective reading strategies. Specially, teachers need to demonstrate to their students how to utilize the reading strategies and knowledge that they bring from their first language in order to cope with reading in an EFL classes (Carrell \& Eisterhold, 1988).

Recent studies on teaching reading strategies showed that they have connections with teachers' beliefs. So, the relationship between teachers' beliefs and instructional practices has increasingly attracted attention in recent years in mathematics and bilingual instruction (Mora, 1999, cited in Cummin, et al., 2004). This relationship has also gained the necessary attention of reading experts (National Reading Panel [NRP], 2000).

An increasing interest in teachers' beliefs about teaching reading strategies and the relationship with their practices has led to an increasing attention on the beliefs of teachers. Clark and Peterson (1986) indicated that teachers' beliefs constitute a major category of teachers' thought processes. Muijs and Reynolds (2001) notice that based on the assumption teachers' beliefs are more important to teaching quality than immediately observable behavior, recent literature emphasizes the necessity to focus on teachers' own beliefs about teaching and the students they teach. Poulson, Avramidis, Fox, Medwell and Wray (2001) agree and claim that teachers' beliefs represent an important feature of quality teaching that deserves consideration in any attempt to improve learning.

Hativa and Goodyear (2002) reported that research has pointed toward a strong, though not necessarily simple, link between teachers' beliefs and knowledge and their classroom practices to enhance student performance. Chou (2008) and Wellingham (2007) noted that there is a connection between teachers' beliefs about reading and their classroom practices. In fact, a few more recent studies have explored this connection (e.g., Almaz, 2015).

Many researchers have examined and gave recommendations on the relationship between teachers' beliefs about how reading takes place and how students are helped to develop 
these reading strategies in their reading (Chou, 2008). However, empirical investigation of this relationship has been limited and is a relatively recent development (Minwagaw, 2009; Pace \& Powers, 1981). On the other hand, Chou (2008) contends, "the little amount of studies on investigating teachers' beliefs in the area of second language reading instruction have indicated an unclear picture of teachers' belief construct in teaching reading" (p. 192). Therefore, there is a need for more research on exploring teachers' beliefs about reading and the actual classroom practices during teaching reading.

Chou (2008) conducted a study based on the assumption that teachers are highly influenced by their beliefs. He investigated the construct of teachers' belief systems about reading approaches among 42 university instructors and explored the degree of discrepancies or consistencies between teachers' beliefs about reading theories and their practical teaching activities in the EFL setting of Taiwan. The findings showed that there were no significant differences between the participants' beliefs and their use of each reading approach.

Several themes can be identified in research on teacher beliefs. However, recent researches have tried to connect teachers' beliefs to classroom practices. Teachers' beliefs in relation to classroom practices are by far the most researched theme in ESL/EFL teacher cognition research. Gatbonton's (1999) study, relating to the patterns of pedagogical knowledge of seven experienced ESL teachers in the USA, revealed that teachers' thoughts and decisions are related largely to language concerns (such as explaining new vocabulary and creating contexts for meaningful language use). In contrast, Nunan's (1992) study of the interactive decisions of nine ESL teachers in Australia found that teachers' decisions are related little to language concerns. Issues of classroom management such as the pacing and timing of lessons, the amount of teacher talk and the quality of their instructions and explanations to the students appeared to be more of a concern for the teachers in Nunan's study.

Recent research in the area of reading comprehension has focused on reading-related strategies, and strategy-training studies. For the most part, such studies have found that strategy training leads to improved reading performance (Singhal, 2001).

In a study, Basturkmen, Loewen, and Ellis (2004) found evidence of incongruence between EFL teachers' stated beliefs and their classroom practices related to form-focused instruction. These inconsistencies related mainly to when it was appropriate to focus on form during a meaning-focused lesson and the type of error correction techniques to be employed. Basturkmen, et al. (2004) indicate that it may be better to view the stated beliefs of teachers to be "potentially conflictual rather than inherently inconsistent" (p. 268), suggesting that the differences between beliefs and practices are challenges that teachers need to resolve. This follows from several reports of incongruence between teachers' stated beliefs and observed (or reported) practices in mainstream education (Fang, 1996). As Fang notes, such inconsistencies are not unexpected due to the demands and complexities of classroom life which constrain teachers' abilities to provide instruction that aligns perfectly with their beliefs.

Discovering the best strategies to achieve fluent reading with adequate comprehension, and identify what techniques or processes the learners choose to access, is the goal of research in reading strategies. Moreover, the effectiveness of teaching reading strategies has been the subject of over "500 studies in the last twenty five years" and what these studies have concluded is that "strategy instruction improves comprehension" (Wellingham,2007, p. 39). 
However, interplay between teachers' beliefs and practice within the context of recent developments in teaching English language reading in colleges in Ethiopia has not been explored yet. It is this interconnection that motivated the present study aimed at investigating college EFL instructors' beliefs and practices of reading.

\section{Statement of the Problem}

It is generally acknowledged that instructors have theoretical beliefs about EFL learning and teaching and that such beliefs and theories tend to shape the nature of their instructional practices (Gebel \& Schrier, 2002). However, while significant contributions to understanding the relationship between instructors' beliefs and practices have been made in first language (L1) education contexts, studies investigating teachers' cognitions in foreign language (FL) contexts have been limited (Borg, 2006). Furthermore, little work has been done on college of teacher education instructors' beliefs and practices in an EFL college setting (Borg, 2006). Similarly, scant attention has been paid to instructors' beliefs in Ethiopian college of teacher education, with the exception of Girma's (1994) investigation in to the reading strategies of Addis Abeba University first year students, which does not include teachers' beliefs and Minwagaw's (2009) research on an EFL teachers' expressed beliefs and actual practices in testing reading skills in the case of grade 10 three high school students of West Gojjam Zone. To the researchers' knowledge, no study was done by integrating both teachers' beliefs about teaching reading and their classroom practices to Amhara National Regional State Colleges of Teacher Educations' context.

This study, thus, hopes to address the need to identify the belief hold by the English language teachers of College of Teacher Education and the actual classroom practices in the context of government teacher education colleges. This need arises from the fact that the English language teaching and learning at the colleges is essentially student course material-based, with a number of activities based on these reading texts. English language instructors are required to develop students' reading strategies and reading skills, enabling them to effectively communicate in other academic subjects and learning contexts. Thus, by examining the connections between instructors' beliefs about reading strategies and their classroom practices, this study hopes to help teachers become better reading teachers and increase student reading ability in English and in core subject areas.

\section{Objective of the Study}

The general objective of the present study is to find out to what extent EFL instructors are aware of the importance of these strategies and whether or not they translate their beliefs into relevant instructional practices.

Specifically, the study is designed to achieve the following research purposes:

- To find out the instructors' beliefs about teaching reading strategies in the sample colleges.

- $\quad$ To examine the extent to which their beliefs are reflected in their reading classroom practices. 


\section{Research Questions}

Based on the above objectives, the following research questions were formulated to guide this research.

- What are instructors' beliefs about the teaching of reading strategies in Colleges of Teacher Education in Amhara Regional State?

- How are reading strategies taught in actual reading classrooms in Colleges of Teacher Education in Amhara Regional State?

\section{Significance of the Study}

It is hoped that the findings of the study may have the following contributions:

- Colleges of Teacher Education instructors who participated in this study would be beneficiaries because they will be familiar with reading strategies that can help them improve their teaching practices in reading skills .and

- $\quad$ The study might highlight the important role of instructors' beliefs on teaching reading strategies to students in general and students at the selected Colleges of Teacher Education in particular. It may strengthen the theoretical basis for the application of reading strategies in the classroom.

\section{Delimitation of the Study}

Students' success or failure in acquiring a language can be affected by many intervening factors. Teaching reading strategies should be taken into consideration, among others. However, this study only focused on the teaching of reading strategies by EFL instructors at 4 Colleges of Teacher Education, which are found in Amhara National Regional State, Ethiopia.

\section{RESEARCH DESIGN AND METHODOLOGY}

\section{Design of the Study}

A mixed-methods research design was used in this study. The rationale for choosing mixed approach was that both quantitative and qualitative data provide a better understanding of the research problem than employing only qualitative or quantitative approaches.

\section{Study Site, Samples and Sampling Procedure}

The sites of the target population for this study were the Colleges of Teacher Education students in Amhara National Regional State Council, Ethiopia. In this region, there are 10 Administrative Zones. In the zones, there are about 10 colleges. Among the 10 Colleges, 4 colleges, namely, Debre Birhan, Sekotta, Gondar and Debre Markos were selected by simple random sampling. To select the participating instructors for the study from the 4 selected colleges of teacher education, again, simple random sampling technique was used. Thus, the sample sizes for this study were 26 instructors.

\section{Instruments}

This study applied questionnaire, observation and post interviews. 


\section{Questionnaire}

The study employed the "Teaching Reading Strategies Questionnaire" devised by (Chou, 2008). The questionnaire was on 'Reading Strategy'. It is a two page questionnaire which consists of a mixture of close-ended questions having Likert Scales from 1 to 5, in which 1 indicates the 'Strong disagreement' on a statement, 2 indicates 'Disagreement', 3 indicates 'Undecided', 4 stands for 'Agreement' while 5 refers to 'Strong agreement' of the item on teachers' beliefs about reading strategies. The questionnaire in part one investigates instructors' beliefs about the importance of reading strategies in reading comprehension. Part two investigates instructors' perceived practice on reading strategies in teaching reading. Section one contains 14 identical elements that are considered important factors in reading comprehension.

The 14 items are classified into six categories of reading strategies. Items 1-3 refer to linguistic knowledge, such as studying vocabulary or grammar. Item 4 is about translation, namely translating English texts into L1. Items 5-8 are related to conceptually-driven basis, such as understanding the connections between paragraphs. Items 9-14 are related to cognitive strategies, such as guessing, scanning or skimming. Part two is on instructors' perceived practice of English Language reading strategies. The questionnaire has three frequency scales 1 to 3 in which 1 indicates 'Always' on a certain statement, 2 indicates 'Sometimes' while 3 refers to 'Not at all used' of the items.

\section{Observation}

Lesson observations in this study aimed to obtain direct information on English Language instructors' teaching practices. Each instructor was observed three successive 40-minute lessons. The lessons were not video recorded to avoid artificiality on the part of instructors and minimize frustration among students. The strategies included the use of a particular activity related to the teaching of reading, such as activating prior knowledge before reading a text, the preference for reading aloud or silently, or the inclusion of a discussion in groups or with the whole class about a text, to be able to gain insights into the factors behind the instructors' behaviours as they prompt questions. Structured check list and field notes were used to see how far the reading strategies were applied.

\section{Data Analysis Techniques}

The data gathered from teachers through different instruments such as questionnaire and classroom observation were analyzed both quantitatively and qualitatively. To make things clear, the data gathered trough the questionnaire was analyzed with the use of percentages, mean scores and one sample t-tests. The SPSS version 20 soft ware was used to compute the quantitative data analysis. Moreover, the qualitative data was thematically described using themes emerging out of the data as categories and referring the basic research questions of this study.

\section{Research Ethics}

To ensure respect and to promote healthy relationships with the respondents of this study and to keep the scientific regor in doing this study, the researchers made an effort to adhere to basic ethical principles. Creswell (2009) and Marczyk et al (2005) recommend that it is 
necessary for researchers to be confidential, protect participants' rights and privacy. They suggest that obtaining permission from the participants is one of the safest ways to protect participants' rights. Hence, the researchers first got consent from the deans of the colleges, and the instructors to conduct the research in those colleges. Then, researchers made a rapport with classroom instructors before they participated in this study. The researchers told them the purpose and advantage of the study to the participants and asked them whether or not they were willing to take part in the study. As instructors agreed to get involved in the study, the researchers made the research in the sample colleges.

\section{DATA ANALYSES AND FINDINGS}

It deals with the analysis of the research data obtained from teachers about their beliefs on English language reading strategies and their actual classroom practices through questionnaire and observation. The questionnaire was first designed with five point Likert scale and thereby reduced to three for ease of analysis after receiving the data from the respondents.

Table 1: Teachers' beliefs about the Importance of Reading Strategies

\begin{tabular}{|l|l|l|l|}
\hline Belief statements & Agree & Undecided & Disagree \\
\hline $\begin{array}{l}\text { Vocabulary in context should be taught before } \\
\text { teaching reading. }\end{array}$ & $5(19.23)$ & $6(23.07$ & $15(57.69)$ \\
\hline Grammar should not be taught in reading classes. & $5(19.23)$ & $7(26.92)$ & $14(53.84)$ \\
\hline Reading aloud the text helps to teach reading. & $6(23.07)$ & $7(26.92)$ & $13(50)$ \\
\hline Translating the Text into Mother tongue is not helpful. & $8(30.76)$ & $6(23.07)$ & $12(46.17)$ \\
\hline $\begin{array}{l}\text { Activating prior knowledge or background knowledge } \\
\text { about the reading content integrates prior knowledge } \\
\text { to the topic read. }\end{array}$ & $\begin{array}{l}14 \\
(53.84)\end{array}$ & $4(15.40)$ & $8(30.76)$ \\
\hline $\begin{array}{l}\text { Connecting pach paragraph helps whole } \\
\text { understanding of the passage. }\end{array}$ & $13(50)$ & $6(23.07)$ & $7(26.92)$ \\
\hline Understanding the types of text enhances reading. & $12(46.15)$ & $6(23.07)$ & $8(30.76)$ \\
\hline $\begin{array}{l}\text { Title introduction enhances readers to get clues about } \\
\text { the reading text. }\end{array}$ & $15(57.69)$ & $5(19.23)$ & $6(23.07)$ \\
\hline $\begin{array}{l}\text { Guessing the meaning of words simplifies difficulty in } \\
\text { understanding text. }\end{array}$ & $19(73.07)$ & $3(11.5)$ & $4(15.38)$ \\
\hline Scanning helps get specific information. & $15(57.69)$ & $3(11.5)$ & $8(30.76)$ \\
\hline Skimming helps get main idea. & $14(53.84)$ & $8(30.76)$ & $4(15.38)$ \\
\hline Summarizing the story helps internalize text. & $13(50)$ & $6(23.07)$ & $7(26.92)$ \\
\hline $\begin{array}{l}\text { Predicting the main idea of the following paragraph } \\
\text { integrates the ideas in the text. }\end{array}$ & $5(19.23)$ & $7(26.92)$ & $14(53.84)$ \\
\hline $\begin{array}{l}\text { Activating silent reading helps to check } \\
\text { comprehension }\end{array}$ & $6(23.07)$ & $13(50)$ & $7(26.92$ \\
\hline
\end{tabular}

Instructors were asked to confirm their beliefs about English language reading strategies. Having receiving the data, analysis was carried out to examine instructors' beliefs about English language reading strategies. As can be seen from Table 1, 15(57.69\%) of the English Language instructors believe that vocabulary in the context should not be taught before teaching reading. However, closer to similar percentages (53.84\%) of instructors believe that grammar should be taught in reading classes. Fifty percent of instructors believe that reading 
the text aloud does not help to teach reading. Forty six percent of the respondents believe that translating the text in to mother tongue is helpful. Similarly, fifty three percent of instructors believe that activating prior knowledge integrates prior knowledge to the topic. The result in the same table portrayed that fifty percent of the respondents believe that connecting each paragraph while reading helps readers understand the whole paragraph.

The results in Table 1 also depicted that 12(46\%) of instructors believe that understanding the text as an instrument enhanced good reading while 15(57\%) agreed introducing the title is one of the strategies to help read better. As seen from instructors' responses, 19(73\%) of them believe that guessing the meaning of words simplifies difficulty in understanding text. Concerning scanning strategy, 15(57\%) of instructors agreed that teaching reading through scanning is an instrument to get specific information. Regarding skimming strategy, 14(53\%) of the instructors believe that skimming is helpful to get the gist of reading text. $13(50 \%)$ instructors' respond that summarizing the story enhances internalizing and understanding reading. However, 5(19\%) instructors do believe that predicting the main idea of the following paragraph integrates the ideas in the text. In the same vein, only $6(23 \%)$ instructors believe that activating silent reading helps to check comprehension. This item by item analysis has clearly uncovered the strategies which instructors mostly favour. However, to examine their overall beliefs, one sample t-test was calculated as indicated in the Table 2 below.

Table 2: One sample t-test results on teachers' beliefs of reading strategies

\begin{tabular}{|c|l|l|l|l|c|}
\hline Theme & $\begin{array}{l}\text { Observed } \\
\text { mean }\end{array}$ & $\begin{array}{l}\text { Expected } \\
\text { mean }\end{array}$ & Std & df & Sig. \\
\hline $\begin{array}{l}\text { English Language Instructors' belief } \\
\text { statements }\end{array}$ & 42 & 37 & 3.11 & 29 & .000 \\
\hline
\end{tabular}

To examine instructors' beliefs item by item analysis was carried out. However, to measure the overall picture of instructors' beliefs, one sample t-test was calculated. The result in Table 2 depicts that the observed mean significantly exceeds the expected mean. There exists high consistence of results between the item by item analysis and one sample t-test. This shows that teachers' have strong beliefs about English language reading strategies.

Table 3: Instructors' perceived practice of English Language reading strategies

\begin{tabular}{|c|l|l|l|l|l|}
\hline Theme & $\begin{array}{l}\text { Observed } \\
\text { mean }\end{array}$ & $\begin{array}{l}\text { Expected } \\
\text { mean }\end{array}$ & Std & Df & Sig. \\
\hline $\begin{array}{l}\text { English Language Instructors' perceived } \\
\text { practices }\end{array}$ & 15 & 18 & 2.13 & 29 & .000 \\
\hline
\end{tabular}

Observation was conducted to see whether or not instructors are employing English reading strategies in their reading classes. The observation result of instructors' actual classroom practice in applying reading strategies indicates that there exists significant mean difference between the observed and the expected means in favour of the expected mean. This implies that instructors do not actually practice reading strategies in their reading classes.

\section{Discussion of the Findings}

Studies on the relationship between instructors' beliefs about reading strategies and their actual classroom practices investigated whether or not instructors changed their beliefs in to 
actions. Most of the studies showed that there were positive and strong relationship between instructors' beliefs and their reading instructional practices. Supporting this finding, researchers (e.g., Chou, 2008; Kuzborska, 2010) proved that instructors' beliefs influence their practices in the classroom.

The above findings demonstrated that Teacher Education College instructors believe that teaching reading strategies are so crucial. The findings indicated that guessing the meaning of difficult, key vocabulary in context, understanding the text, scanning the text, teaching grammar, and skimming are the most significant strategies in teaching reading skill in English.

Several studies disclosed consistent relationships between instructors' believe and classroom practices. For example, Johnson (1992) examined the relationship between English as second language teachers' beliefs and their actual classroom practices, and said that there was a clear relationship between teachers' teaching practices and their beliefs about these practices. Smith (1996) argued that the curriculum design, the selection of learning tasks and teaching approaches are clearly influenced by teachers' beliefs. However, the present study was found inconsistent with these findings.

Therefore, the present study was consistent with the findings of earlier studies, such as Basturkmen, Loewen and Ellis (2004) and Khonamri and Salim (2010), to mention few. Basturkmen, Loewen and Ellis (2004) found that there is an inconsistent correlation between second language teachers' beliefs and their actual classroom practices related to formfocused implementation. Khonamri and Salim (2010) also concluded that teachers do not reflect what they believe in the actual classroom practices. They also concluded that there is inconsistency between EFL teachers' beliefs and practicing teaching reading strategies.

\section{Recommendations}

This study suggested that in order to change instructors' practices, there is a need to change their held beliefs about the practices. The main implication of the present study is that English language instructors' should adjust their beliefs to their practices. Thus, instructors should be trained to admit how their beliefs and school setting contribute to their practices. This is because training instructors may show the gap between what they would ideally like to do and what they actually do can be narrowed or avoided by making them aware of their strengths and weaknesses and helping them to address how to improve their practices and become more effective practitioners.

\section{REFERENCES}

American Institutes for Research (AIR) (2012). Ethiopia Teach English for Life Learning (TELL) Program: Ethiopia English Early Grade Reading Assessment: Data Analytic Report. A.A: USAID.

Amlaku, B. (2010). Language policies and the role of English in Ethiopia. A presentation paper at The $23^{\text {rd }}$ Annual conference of IATEFLBESIE(19-21), Bielefeld, Germany.

Basturkmen, H., Loewen, S., \& Ellis, R. (2004). Teachers' stated beliefs about incidental focus on form and their classroom practices, Applied Linguistics, 25(2), 243-272.

Borg, S. (2006). Teacher cognition and language education: Research and practice. London: Continuum. 
Carrell, P.L. \& Eisterhold, J. C. (1988). Schema theory and ESL reading pedagogy. In Carrell, P. L., Devine, J. \& Eske, D. E. (Eds.). Introduction: Interactive approaches to second language reading, pp.73-92. NY: Cambridge University Press.

Chou, Y. C. (2008). Exploring the reflection of teachers' beliefs about reading theories and strategies on their classroom practices, Feng Chia Journal of Humanities and Social Sciences, 16, 183-216.

Creswell, J. W. (2009). Research Design Qualitative, Quantitative, and Mixed Methods Approaches (3rd ed.). Thousand Oaks, CA: Sage.

Cummin, C. L., Cheek, E. H., \& Lindsey, D. J. (2004). The Relationship between Teachers' Literacy Beliefs and their Instructional Practices: A Brief Review of the Literature for Teacher Educators, E-Journal of Teaching \& Learning in Diverse Settings,1(2), 175-188.

Damitew, A. (2012). Teaching reading skills in English as a foreign language through interactive classroom teaching versus plasma teaching with reference to Grade Ten Students in Addis Ababa. (Unpublished PhD Dissertation): Addis Ababa University.

Debru, A. (2015) Investigating the practice of teaching English reading and its challenges in the First Cycle Primary Level. (Unpublished PhD Dissertation): Addis Ababa University.

Donaldson, R. S. (2011). What classroom observations reveal about primary grade reading comprehension instruction within high poverty schools participating in the federal reading first initiative. All Graduate Theses and Dissertations. Paper 987. Retrieved from http://digitalcommons.usu.edu/etd/987

Fang, Z. (1996). A review of research on teacher beliefs and practices, Educational Research, 38(1), 47-65.

Gatbonton, E. (1999). Investigating experienced ESL teachers' pedagogical knowledge, Modern Language Journal, 83(1), 35-50.

Gebel, A., \&Schrier, L. (2002). Spanish language teachers' beliefs and practices about reading in a second language. In Sullivan, J. H. (Eds.), Literacy and the second language learner. (pp. 85-109). NC: Information Age Publishing.

Hativa, N.,\& Goodyear, P. (Eds.). (2002). Teacher thinking, beliefs and knowledge in higher education. Kluwer Academic Publishers.

Khonamri, F., \& Salimi, M. (2010). The interplay between EFL high school teachers' beliefs and their instructional practices regarding reading strategies, Research on Youth and Language, 4(1), 96-107.

Kinzer, C. K. (1988). Instructional frameworks and instructional choices: Comparisons between pre-service and in-service teachers, Journal of Literacy Research, 20(4), 357-377.

Kuzborska, I. (2010). The relationship between EFL teachers' beliefs and practices in reading instruction to advanced learners of English in a Lithuanian University context. (Unpublished doctoral dissertation). University of Essex. Colchester, UK.

Marczyk, G., \& DeMatteo, D. (2005). Essentials of research design and methodology. U.S.A: John Wiley \& Sons, Inc.

Ministry of Education (2008). General Education Quality Improvement Package (GEQIP) for Ethiopia. USAID.

Muijs, D., \& Reynolds, D. (2001). Being or doing: The role of teacher behaviors and beliefs in school and teacher effectiveness in mathematics, a SEM analysis. In annual meeting of the American Educational Research Association, Seattle.

National Reading Panel (US), National Institute of Child Health, \& Human Development (US). (2000). Teaching children to read: An evidence-based assessment of the scientific research literature on reading and its implications for reading instruction. National Institute of Child Health and Human Development, National Institutes of Health. 
Nunan, D. (1992). Research methods in language learning. Cambridge: Cambridge University Press.

Oxford, R. L. (1990). Language learning strategies: What every teacher should know. New York, NY: Newbury House Publisher.

Pace, A. J., \& Powers, W. C. (1981). The relationship between teachers' behaviours and beliefs and students' reading. In Edwards, J. R. (Ed.), The social psychology of reading (pp. 99115). Silver Spring, MD: Institute of Modern Language.

Singhal, M. (2001). Reading Proficiency, Reading Strategies, Metacognitive Awareness and L2 Readers, The Reading Matrix. 1(1), 1-23.

Smith, D. B. (1996). Teacher decision making in the adult ESL classroom. In Freeman, D. \& Richards, J. C. (Eds.), Teacher learning in language teaching (pp. 197-216). Cambridge: Cambridge University Press.

Snow, C. (2002). Reading for Understanding: Towards an R\&D Program in Reading Comprehension. California: RAND.

Temesgen. M. (2009). EFL Teachers Expressed Beliefs and Actual Practices in Testing Reading Skills. (Unpublished Ph.D. Thesis). School of Graduate Studies. Addis Ababa University.

Transitional Government of Ethiopia. (1994). Education and training policy: Addis Ababa: EMPDA

Willingham, T.D. (2007).The usefulness of brief instruction in reading comprehension. Woods, D. (1996). Teacher Cognition in Language Teaching. Cambridge: Cambridge University Press.

Ygzaw, A. (2011). Effects of Teacher Mediation on Student Concepts and Approaches to Reading. Berlin: VDM Verlag Dr. Muller GmbH \& Co. KG.

\section{Acknowledgement}

We would like to disclose our heartfelt recognition to the College of Education and Behavioural Sciences in particular and the University in general for funding this research project.

\section{Biographical notes:}

Solomon Melesse completed his First Degree in Pedagogical Sciences, Master's Degree in Curriculum and Instruction, and his PhD in Curriculum Design and Development both from Addis Ababa University, Ethiopia. He had been a high school principal for 5 years and Education Senior Expert at Amhara Region for 4 years. Moreover, he has been teaching at Bahir Dar University for the last 14 years. He is now an Associate Professor in Curriculum Design.

Chanyalew Enyew completed his First Degree in Foreign Language, Master's Degree in Curriculum and Instruction, and his PhD in Foreign Language both from Bahir Dar University, Ethiopia. He had been a high school teacher for 18 years. Moreover, he has been teaching at Bahir Dar University for the last 11 years. He is now an Assistant Professor in Foreign Language Instruction. 